31 ( 6 ) : 503 505, 1981

\title{
Radiology-Pediatrics Conference
}

\section{Hyperlucent lung}

\author{
高 橋 美貴子, 平 敷 淳 子 \\ 群馬大学医学部附属病院中央放射線部 (部長: 永井輝夫教授)
飯 山三男, 田島公夫
田沢昌道, 黒 梅 恭 芳*
前橋済生会病院，小児科 \\ *群馬大学医学部小児科学教室（主任：黑梅恭芳教授)
}

(昭和56年 8 月 10 日 受付)

症例 $: 1$ 歳 7 力月, 男児

主訴：咳嗽, 喘鳴, 発熱

家族歴，既往歴には特記すべきことはない。

現病歴：本年 5 月 16 日，ピーナッツ入り煎餅を食 へ， 突然，咳嗽，喘鳴，口唇チアノ一ゼ，呼吸困難 発作出現. 10分位で発作は軽快した。翌日, 発熱, 咳嗽が出現し，肺炎を疑い，抗生物質の投与を開始 した。しかし，咳嗽と喘鳴は増強し，咳嗽時嘔吐， 食欲低下のために入院となった。入院時, 体温 $39^{\circ} \mathrm{C}$, 呼吸数 $62 /$ 分と多呼吸で, 鼻翼呼吸, 吸気性陥凹, 口 唇周囲蒼白を認めた。胸部では, 右呼吸音減弱, 喘 鳴，湿性ラ音を聴取した。血沈 $77 \mathrm{~mm} / 1$ 時間, CRP $6(+)$, 白血球増加と核左方移動の所見であった。図 1 は入院後一日目の胸部単純正面像で, 右肺の $\mathrm{X}$ 線

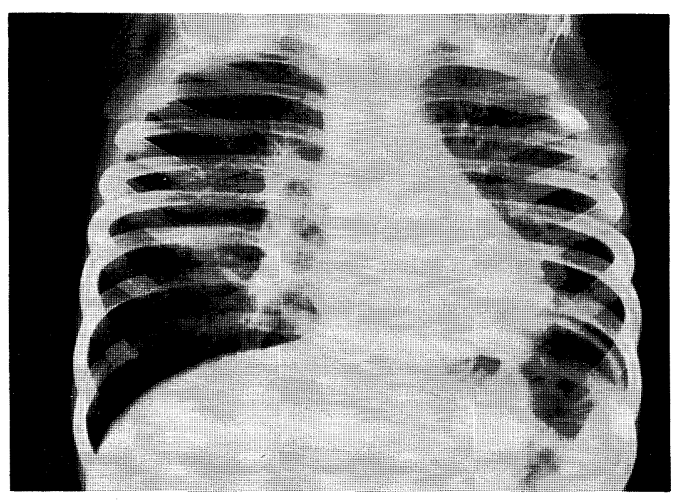

図 1 胸部単純正面像 右肺のX線透過性の増大と容積増加が見られ， 心血管陰影は左へ偏位している。
表 1 Hyperlucent Lung

1. Bilateral

1) Asthma

2) Diffuse bullous emphysema

3) Bronchiolitis (Acute diffuse bronchiolitis of infants)

4) Tracheal or laryngeal obstruction/compression (foreign body, vascular ring, tumor, tracheomalacia, etc)

5) Congenital heart disease ; usually cyanotic

2. Unilateral

A. Volume loss

1) Absent or hypoplastic pulmonary artery ; pulmonary branch stenosis

2) Congenital lobar emphysema ; Swyer-James syndrome

B. Volume enlarged

1) obstructive hyperaeration (foreign body, neoplasm, inflammation)

2) Lobar collapse with compensatory overdistension of remaining lobes)

3) Congenital lung cyst

4) Cystic adenomatoid malformation

透過性の増大と容積増加が見られる。心血管㓌影は 左へ偏位している. hyperlucent lung で考えられる 疾患を表 1 に示した。本例は，一側性の容積增大を 伴う hyperlucent lung であり，臨床経過を考慮する と，ピーナッツによる右主気管支の気管支内異物が 最も考之られる。気管支喘息患者の mucous plug の 像は，気道内異物と非常に似たX線所見を呈する。 幼児の気道内異物は1), 食物とくにピーナッツであ ることが最も多いが, 直接, 異物をX線学的に描出 することはきわめて困難である。したがって，間接 


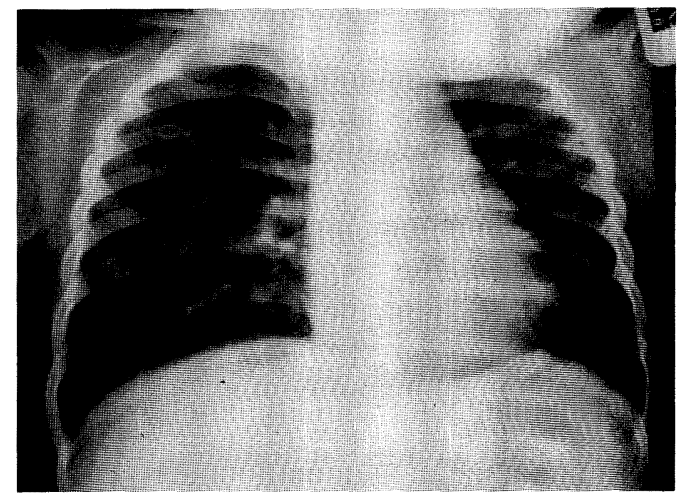

図2-a 胸部単純正面像（呼気時）

心血管㓌影は病側から健側へ偏位し, 病側肺の 容積は増大したままである。

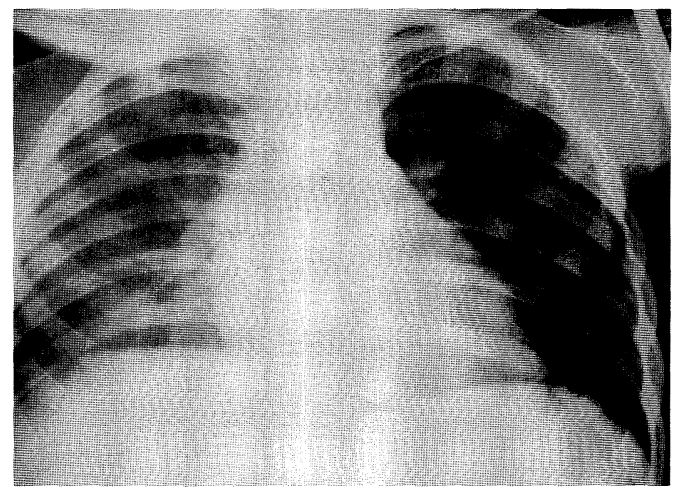

図2-b 胸部単純正面像（吸気時） 心血管除影は病側に偏位し, 病側肺の容積は, 健側に比して減少している。

所見として，異物による気道の完全閉塞によっ て生じた無気肺あるいは，不完全閉塞のための check-valve 機構による肺気腫を証明することに よって診断する，有効な X 線学的検查法としては, (1)適切な吸気呼気時の胸部 X 線写真 (2)胸部透視 (3) ${ }^{99 m} \mathrm{Tc}-\mathrm{MAA} に よ る$ 肺血流シンチグラフィが挙げら れる。肺気腫を呈する症例においては，図 $2(a$, b ）に示す如く, 呼気時では心血管陰影が病側から 健側へ偏位し, 病側肺の容積は增大したままである。 これは, 健側肺からは空気が呼出されるが, 嵌入側 の肺からは出ないためである。一方，吸気時には心 除影は病側に偏位し, 病側肺の容積は健側に比べて 減少している，異物の結果，無気肺を生じな症例で は, 反对に吸気時にむしろ病側と健側との差が明ら
かになる．また，呼気時と吸気時における病側の横 隔膜の高さが変化しないという所見も診断上役立 つ. Richard らの報告 ${ }^{2)}$ では, 気道内異物325症例の うち, 喉頭以下の気道に異物が嵌入したものに対し て, 呼気時胸部写真を撮影し，その正診率は $94 \%$ で あったと述べている。臨床症状から異物の存在が疑 われながら，聴診で呼吸音に左右差が認められず， しかも胸部写真でも異常が見られないような症例で は, ${ }^{99 m} \mathrm{~T} \mathrm{c}-\mathrm{MAA}$ を用いた肺血流シンチグラフィが 有効である ${ }^{3)}$ ここのメカニズムは, 換気不全を呈して いる肺野では, 肺胞換気量の減少つその部位の低酸 素血症 $\rightarrow$ 肺動脈の平滑筋の緊張增加 $\rightarrow$ 血管抵抗の増

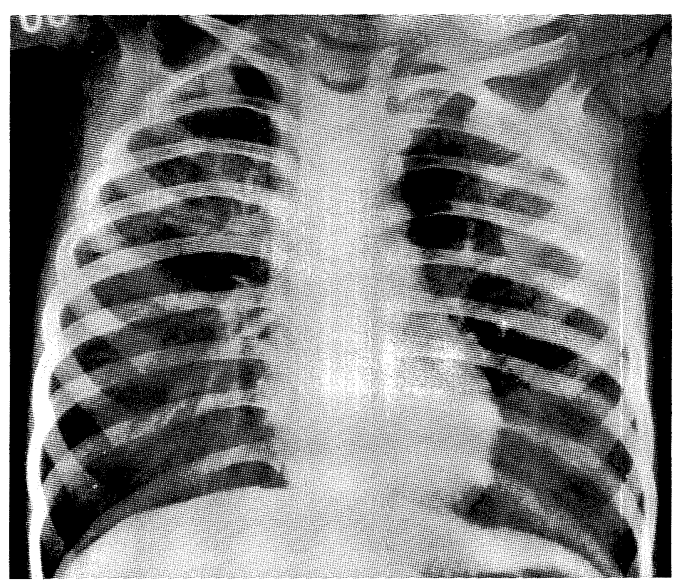

図3- a 胸部単純正面像 著変をみとめない。

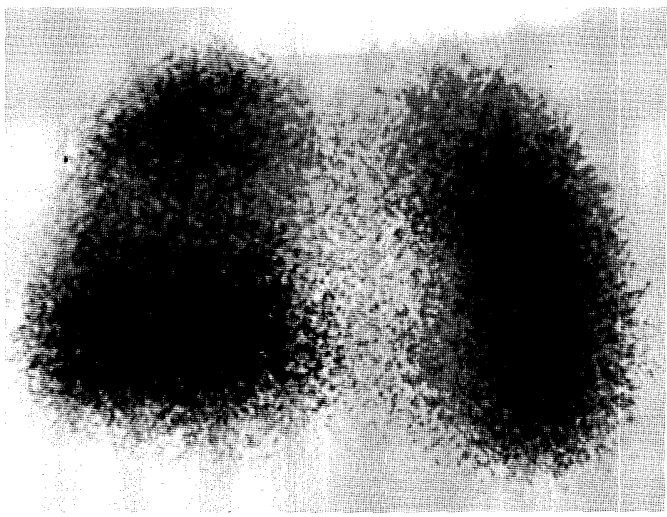

図3-b 肺血流シンチグラム $\left({ }^{99} \mathrm{~m} \mathrm{~T} \mathrm{C}-\mathrm{MAA}\right)$ 右上葉前区において，アイソトープのとりこみ の減少がみとめられる。 
大 一肺血流量の減少をひきおこす。air-trapping を 有するような場合は，さらに機械的な肺血管床の圧 迫が加わるために血流の減少が著明となる。した がって, シンチグラム上, perfusion defect の像を呈 する（図 3-a, b ). 異物除去後， 1 3 日位で肺 血流シンチグラムが正常化することが多い.ゆえに， 肺血流シンチグラフィは気管支内異物の診断法とと もに異物除去後の経過観察にも有効な手段となりう る. 幼児の気道内異物の吸引は非常に多く，危険な 事故であり，窒息による死亡例もある。しかし，か み砕かれたピーナッツは，気管支内まで吸引され， そこに嵌入してしまうため, 症状は比較的軽く, 一 般状態も犯されず，ただ咳嗽，喘鳴などの症状のみ のことが多い。むせた際にピーナッッの破片がいく つか喀出されたとしても，気道内に残存しているか どうか問題となる。迅速な診断のステップには，問
診, 胸部聴診所見に加えて, 呼気時胸部写真, 肺血 流シンチグラフィが有効な手段となる.

本例は, 本院耳鼻科にて, 右主気管支よりピーナッ ツを摘出し, その後, 軽快退院となった。

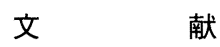

1）松島正視：幼児の気道内異物（特に気管支異 物）の診断と予防。小児科, 17 : 701-706, 1976.

2) Richard, L.W., et al. : Assisted expiratory chest radiography. Radiology, $130: 538-539$, 1979.

3) E. George Kassner, et al. : Persisting perfusion defects after bronchoscopic removal or spontaneous expulsion of aspirated foreign objects. Radiology, 121 : 139-142, 1976. 